\title{
A construção da figura heroica grega: passado micênico e arcaico.
}

\section{Breno Coltro da Costa*, Pedro Paulo Abreu Funari.}

\section{Resumo}

Acessar a mitologia heroica grega a fim de descobrir nela uma história mais remota daquele mesmo povo é um exercício praticado há muito tempo e que requer cuidado. Através do uso de diversas fontes (Ciclo Épico, tragédias, compêndios mitológicos, poesia, etc.) e de discussão bibliográfica, lançamos luz do quanto tais mitos nos ensinam sobre sua sociedade e seus valores culturais, buscando delimitar temporalmente as influências de cada época (micênica, arcaica, clássica).

\section{Palavras-chave: \\ Mitologia grega, Grécia Antiga, Sociedade Micênica}

\section{Introdução}

Quem lê o Ciclo Épico pode imaginar estar lendo sobre a Era do Bronze grega e uma realidade de acordo com os núcleos urbanos e políticos da época. Contudo, a saga da Guerra de Troia carrega em seu bojo muito mais características da época em que se consolidou (em torno do século VIII a.C.) do que da época micênica, i.e. reflete mais a conjuntura contemporânea da Grécia Arcaica do que daquela do período na qual a narrativa se passa.

Dentre nossos objetivos, estavam entrever qual memória os próprios gregos tinham de si e como esta era mobilizada no presente, quais valores veiculavam e, portanto, quais comportamentos deviam ser emulados.

\section{Resultados e Discussão}

Para atingirmos nossos fins, utilizamo-nos dos épicos de Homero, de fragmentos do Ciclo Épico perdido, de tragédias de Sófocles e de Eurípedes, dos poemas de Píndaro e das compilações de Apolodoro e de Apolônio.

Os épicos são oriundos da tradição oral e consolidam-se pela mesma época em que a escrita do grego antigo se dissemina pelo Egeu. Tal período se enquadra no final do que pode ser chamado por Grécia Arcaica. Sendo ajustado de geração em geração conforme a realidade de seus ouvintes, podemos afirmar que embora haja um substrato mais antigo, as dinâmicas sociais que entrevemos pelo comportamento dos personagens corresponde ao prelúdio da pólis.

Desta maneira, sobretudo na Odisseia, o retrato da pirataria e de incursões constantes, a organização da comunidade ao redor do oikos, núcleos familiares ao redor dos quais gravitava a vida social e a relação de amizade-hospitalidade xenia, elaborada em cima de um sistema de troca de presentes, eram todos partes da sociedade arcaica que ainda apresentava tais mecanismos em seu dia a dia. Viriam a se dissolver na pólis quando da supressão das identidade e lealdade familiares frente à cívica 1 .

As sociedades do bronze no Egeu, como a micênica e outras anatolianas, obedeciam a um sistema matrilinear. Seguindo tal padrão, vemos que a mitologia nos fornece linhagens de rainhas autóctones, contudo de reis adventícios ou, também presente, de linhagens reais que se alternam no trono. Isso é possível devido à troca entre duas ou mais famílias no poder, como a de $\operatorname{Argos}^{2}$. Isso justifica a mobilidade dos heróis gregos e a forte associação identitária à genealogia que as famílias desenvolviam e não à terra, devido ao descompasso entre ambas.
O cultivo da oratória, associada à capacidade de convencer e de comandar ${ }^{3}$, da força, da inteligência/astúcia, da obtenção de glória e honrarias, da centralidade dos banquetes na socialização e da devida parte de cada um (inclusive divina) ${ }^{4} \mathrm{e}$ as funções sagradas dos basileis, evocadas em rituais e na arbitragem de disputas, são valores passados pelos épicos.

Os mesmos valores de xenia, de piedade e de justiça, de bravura e de glória são reiterados e discutidos em peças trágicas como as de Eurípedes ${ }^{5}$, que mantém grande sintonia com os poemas oriundos séculos atrás.

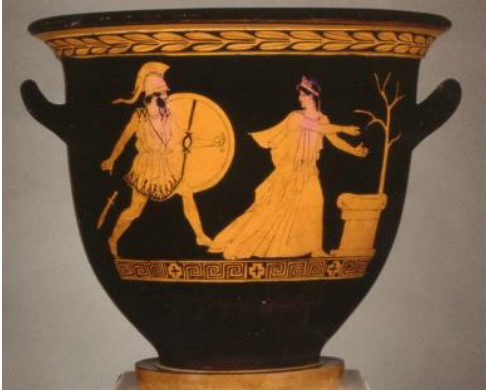

Figura 1. Helena e Menelau no Saque de Tróia ${ }^{6}$ Conclusões

Os textos épicos e mitos heroicos gregos não são uma boa base para se estudar a Grécia Micênica. O uso de tais materiais podem evidenciar resquícios dessa época, contudo grande parte do material fornece uma visão da Arcaica. Ainda assim, podemos ver a permanência de alguns valores culturais que perpassam esses séculos, ocupando o palco nos festivais da Atenas Clássica.

\section{Agradecimentos}

Agradeço ao CNPq pela bolsa de fomento PIBIC que recebi no decorrer do ano de pesquisa e ao meu orientador Funari que sempre teve paciência comigo e me ajudou quando precisei.

\footnotetext{
${ }^{1}$ FINLEY, M. I. The world of Odysseus. New York, NY: New York Review Books, c2002.

${ }^{2}$ FINKELBERG, Margalit. Greeks and pre-Greeks: Aegean prehistory and Greek heroic tradition. Cambridge University Press, 2006.

${ }^{3}$ MARTIN, RP. The language of heroes: speech and performance in the Iliad. Ithaca ; London: Cornell University Press; 1992.

${ }^{4}$ NAGY, Gregory. The best of the Achaeans: concepts of the Hero in Archaic Greek poetry. Baltimore: Johns Hopkins University Press, 1979.

5 EURÍPIDES. Duas tragedias gregas: Hecuba e Troianas. Coautoria de Christian Werner. São Paulo, SP: Martins Fontes, 2004.

6 ANDERSON, Michael J. Heroes: mortals and myths in ancient Greece. Edição de Sabine Albersmeier. Baltimore, MD; New Haven: Walters Art
} Museum: Distributed by Yale University Press, c2009, p.207. 